\title{
TOXIC RELATIONSHIP IN ANNA TODD'S WATTPAD STORY AFTER
}

\author{
Rindiani Azzahra, Muhammad Fatih Suhadi \\ Faculty of Litrerature, Universitas Islam Sumatera Utara \\ Medan, Indonesia \\ e-mail: rindianiazahra16@gmail.com
}

Received: 2021-10-16

Accepted: 2021-11-14

\begin{abstract}
This study is conducted to analyze the context of toxic relationships and find out the characteristics and negative impacts of toxic relationships in a story, After, written by Anna Todd, published in 2013. This study uses a descriptive qualitative method because the process of the results and discussion are accomplished descriptively. One of the significant theories used in this research is proposed by Glass (1995) who claims that toxic relationship is any relationship between people who do not support each other, there is conflict and one seeks to undermine the other, a competition, and disrespect and a lack of cohesiveness. The characteristics of toxic relationships which are analyzed are excessive romantic jealousy, egoism (selfishness) of the partner, and lack of honesty. The negative impacts which are analyzed are disrespect and abuse. The results of this study are that toxic relationships are dangerous and should be avoided by a couple to get a harmony.
\end{abstract}

Keywords: abuse, disrespect, egoism, honesty, toxic relationship.

\section{Introduction}

Love is one of the most profound emotions known to human beings. Many people seek its expression in a romantic relationship with a compatible partner. For these individuals, romantic relationships comprise one of the most meaningful aspects of life, and are a source of deep fulfillment. However, relationships are not always romantic. There are also toxic relationships. Even though they are based on love, these relationships tend to have negative impacts on the couple.

After is a young adult romance of Wattpad story written by American author Anna Todd in 2013. Anna Todd, the creator of After, was originally known on Wattpad under the name of Imaginator1D. Anna Todd's writing of the story was inspired by the music and fandom of One Direction, a pop boy band originating from London. The story After has been read millions of times on Wattpad and has been booked into a novel. And also has been adapted into a movie that was released on April 12, 2019.

After is the most famous Wattpad story by Anna Todd. This story is about Tessa Young, an incoming freshman at Washington State University. Tessa is a dedicated student, dutiful daughter, and loyal girlfriend to her high school sweet heart. Entering her first semester of college, Tessa's guarded world opens up when she meets Hardin Scott, a mysterious and brooding rebel who makes her question all she thinks she knows about herself and what she wants out of life. 
Tessa then has a relationship with Hardin, but their relationship has negative impacts on Tessa's life. In the story, it is found that the impacts of toxic relationships are attractive enough to be analyzed.

The subject matter that is analyzed in this study is the toxic relationship experienced by Tessa in the Wattpad story After. The reason why the toxic relationship is analyzed in this study is the impacts of toxic relationship result in many conflicts experienced by Tessa. In addition, this story has hundreds of millions of readers after almost a year on Wattpad. This story has been printed into a novel and published in October 2014. This story has also been translated into over 30 languages and adapted into a movie in 2019.

\section{Literature Review}

A relationship is defined as an enduring association between two persons (Reis, 2001). A relationship is characterized by a stable pattern of interaction between at least two individuals (Asendorpf and Banse, 2000). Two people are said to be in a relationship with one another if they impact on each other and if they are interdependent in the sense that a change in one person causes a change in the other and vice versa (Kelly, 1983).

The Interpersonal Theory of Psychiatry (Sullivan, 1953) suggests that relationships form the essence of personality. The theory proposes that personality is the relatively enduring pattern of recurrent interpersonal situations that characterize a person's life. Sullivan, in his theory, further suggests that significant psychosocial threats to an individual's wellbeing are inherently social in nature. These threats, mainly, are loneliness, isolation, and rejection. Interpersonal loss or failure to form close, supportive relationships contributes to clinical symptomatology; thus, Sullivan locates healthy or unhealthy psychological development in reactions to one's relationships. Neyer and Lenhart (2006) suggest that relationships generate the social context of personality development, and that personality and relationships have a continuous interaction, which in turn may initiate or foster change in personality characteristics. In the long run, continuous reciprocal interactions have strong impacts on health in its broadest sense, including wellbeing, life satisfaction, and longevity. It is this aspect of relationships, as proposed by the interpersonal theory of psychiatry and that makes it compelling to explore individuals' evaluation of their relationships, which is termed 'relationship quality'. Relationship quality is an ambiguous term, potentially encompassing all objective and subjective measures of a relationship (Hardie and Lucas, 2010).

\subsection{Toxic Relationship}

Glass (1995), a California-based communication and psychology expert, defines a toxic relationship as "any relationship between people who do not support each other, where there is conflict and one seeks to undermine the other, where there is competition, where there is disrespect and a lack of cohesiveness."

Wulandari (2019) states that toxic relationship is most dangerous if experienced by young couples. Toxic relationship has negative impacts both psychologically and physically. Psychological impact for people who experience toxic relationship is becoming individuals who are inferior and pessimistic. Even they can be able to hate themselves as a result of negative treatment or words that their partner gives to themselves. 
From the definition above, it can be concluded that toxic relationship is very dangerous for people, both psychologically and physically because of the negative treatments that their partner gives. It brings negative impacts for couples that can change someone's habit for doing bad things.

\subsubsection{Characteristics of Toxic Relationship}

According to Effendy (2019), a toxic relationship is a relationship that is not good both for self or partner by causing someone to feel worse. The characteristics of a Toxic Relationship, including excessive romantic jealousy, egoism (selfishness) of the partner, lack of honesty, giving negative comments or criticism, and feeling not safe in a relationship.

\subsubsection{Excessive Romantic Jealousy}

Excessive romantic jealousy is a complex affective emotion which is akin to the very human nature in intimate relationships; romantic jealousy is also indispensable for social order (Clanton, 1996). White (1981) states that set of thoughts, feelings, and actions follow a threat to self-esteem and / or threaten the existence or quality of the relationship. These threats are generated by the perception of a real or potential attraction between the partner and a (perhaps imaginary) rival" (p.24). Hart and Legerstee (2013) state that jealousy is a state which - depending on the context - can arouse emotions like sadness (loss), anger (treason), or fear or anxiety (loneliness).

There are different types of romantic jealousy. Buunk (1997), subdivides them into: a) reactive jealousy, caused by intimate behavior of a partner with a third party; b) anxious jealousy, focused on the possibility that the couple is sexually or emotionally involved with someone else; c) preventive jealousy, aimed at preventing intimate contact of the partner with a third party upon slight indications of interest.

While developing the Multidimensional Jealousy Scale, Pfeiffer and Wong (1989) argue that jealousy can be: a) emotional jealousy - reaction to the perceived threat; b) cognitive jealousy - concerns about the involvement of the partner in infidelity c) behavioral jealousy - monitoring behaviors.

\subsubsection{Egoism (Selfishness) of the Partner}

Egoism comes from the word ego, which means the individual's perception of himself that affects his actions. So, the ego is the center of consciousness, the natural process of the individual, which is a combination of thoughts, ideas, feelings, memories, and sensory perceptions (Corsini, 2018). So, if someone always puts his own interests first, he is called a selfish person.

The most obvious characteristics of a selfish person, is prioritizing their own interests over the interests of others, difficulty accepting suggestions as long as they are not beneficial to themselves, not cooperative, willing to win alone, little tolerance, lack of empathy, calculation, lack of understanding, stubbornness.

\subsubsection{Lack of Honesty}

To be honest means to speak the truth, even if it is difficult or gets you into trouble. Honest people communicate in an open, upfront way; they do not lie, cheat, steal, or manipulate information to conceal it from others. The exception is occasionally telling a "white lie" to protect someone's feelings (Djaba, 2009: 1). 
Honesty in a relationship is a very real value that we should do everything in our power to keep alive. The health and longevity of the relationship depends upon it. Honesty in a relationship is vitally important because it gives us the assurance that we can trust and rely on the person we love (Khanam, 2013: 1). The lack of honesty in a relationship makes people cannot trust their partner, raises the suspicion, and makes the uncomfortable situation in a relationship. That is why honesty is very important in a relationship.

\subsubsection{Giving Negative Comments or Criticism}

According to Merriam Webster Dictionary, Comment is an observation or remark expressing an opinion or attitude; a judgment expressed indirectly. Giving negative comments means giving negative opinions to someone in order to judge or humiliate someone.

Negative criticism means voicing an objection to something, only with the purpose of showing that it is wrong, false, mistaken, nonsensical, objectionable, or disreputable.

\subsubsection{Feeling Not Safe in a Relationship}

Feeling not safe or in danger in a relationship is one of the fears of people that are trapped in a toxic relationship. Sometimes relationships can be toxic and leave a person feeling insecure or scared. In a toxic relationship, a partner can do physical abuse where your partner pushes you, hits you, or destroys your things. Also control you. Your partner tells you what to do, what to wear, or who to hang out with. They constantly check up on you or use threats (for example, to harm you or themselves) to make you do things. Or even give you pressure. Your partner pushes you to do things you do not want to do or are not ready for, including sex or using drugs and alcohol. They do not take "no" for an answer, and they use threats or ultimatums. (https://kidshelpphone.ca/get-info/healthy-relationships-vs-unhealthy-relationships/)

\subsubsection{Negative Impacts of Toxic Relationship}

Negative impacts of toxic relationship can affect a person both physically and mentally. In addition, toxic relationships can also affect someone's habits. Someone who is affected by the negative effects of a toxic relationship can do things that can harm themselves. A toxic relationship can consist of these various subcategories which are disrespect, inequity, lack of care, mental health issues, abuse, and lack of boundaries (Byrd, 2009). The negative impacts of toxic relationship are explained in the following section.

\subsubsection{Disrespect}

According to Oxford Dictionary (Merriem, 2001), the meaning of the word 'disrespect' is lack of respect or courtesy. Some synonyms of disrespect are dishonor, discourtesy, disesteem etc. Disrespect was also mentioned many times as an element and negative impact of a toxic relationship. When asked how to define an unhealthy relationship, that is about "Negativity, anxiety, disrespect".

Disrespect occurs when there is evident contempt for one partner or between both partners in a relationship, such as hatred or feeling the other is unworthy or beneath themselves. These deal breakers include: Physical and verbal abuse, and infidelity. 


\subsubsection{Inequity}

Inequity is another subcategory and referred to comments about control, wanting to please the other person, and subservience. Inequity in relationships is associated with distress and relationship dissatisfaction. One participant notes: "I think for unhealthy, I think back and there is that feeling of wanting to please the other person, like you did not really want to do something, but you felt a pressure, like to appease that other person."

Equity theory proposes the winning formula of fairness in relationships: one partner's benefits minus their costs, should equal another partner's benefits minus their costs. If one partner perceives a relationship as unfair, they are going to be dissatisfied with it regardless of whether they are over-benefitting or under-benefitting. The longer this feeling of unfairness (lack of equity) goes on, the more likely a couple is to break up.

\subsubsection{Lack of Care}

Caring in intimate relationships is the practice of providing care and support to an intimate relationship partner. Caregiving behaviors are aimed at reducing the partner's distress and supporting his or her coping efforts in situations of either threat or challenge. Caregiving may include emotional support (expressions of care, affection, sympathy, and encouragement) and/or instrumental support (provision of information, advice, and tangible resources). Effective caregiving behavior enhances the carerecipient's psychological well-being, as well as the quality of the relationship between the caregiver and the care-recipient. However, certain suboptimal caregiving strategies may be either ineffective or even detrimental to coping.

Lack of care is the opposite of caring. In lack of care, the partner will not support each other. They will not provide affection, sympathy, or encouragement. They just let their partner through the dark time alone. Lack of care was also noted in responses to taking advantage of someone, taking someone for granted, and manipulating for one's benefit.

\subsubsection{Mental Health Issue}

Mental health refers to cognitive, behavioral, and emotional well-being. It is all about how people think, feel, and behave. People sometimes use the term "mental health" to mean the absence of a mental disorder.

The subcategory of mental health issues was mentioned many times and appeared as a subcategory under toxic relationships. Toxic relationship can cause mental health issues such as depression, anxiety, and obsession.

\subsubsection{Abuse}

Abuse as a subcategory represents emotional and physical abuse. Emotional abuse refereed to responses about manipulation and tearing each other down. Emotional abuse is a way to control another person by using emotions to criticize, embarrass, shame, blame, or otherwise manipulate another person. In general, a relationship is emotionally abusive when there is a consistent pattern of abusive words and bullying behaviors that wear down a person's self-esteem and undermine their mental health. Physical abuse basically involves a person using physical force against people, which causes, or could cause, you harm. Physical abuse in a relationship often starts gradually, such as with a push or a slap, and then becomes progressively worse over time. 


\subsubsection{Lack of Boundaries}

Lack of boundaries is represented by descriptions of dependence and loss of identity. Dependency is represented by participants comments related to not finding strength within self. "A toxic relationship is like an 'A', with the people leaning against each other, and if one person is not there, they both fall." Loss of identity was present throughout with references to having to be a different person. Participants notes: "If you feel like you have to be a different person to have that person want to be with you or be around you, that is not good." "I think also enmeshment is unhealthy, when you define yourself through another person, and I think that is where a lot of problems stem from."

\section{Research Method}

This section discusses the study design that is used in this research. It explains the general procedure in collecting and analyzing the data. Study design is a statement of a general research approach of strategy that is adopted in one particular study or research (Aaker, 2001). In exploring this research, the descriptive method is used.

Descriptive research is unique in the number of variables employed. Like other types of research, descriptive research can include multiple variables for analysis, yet unlike other methods, it requires only one variable (Borg and Gall, 1989). Therefore, the research design adopted in this study is descriptive qualitative because the process of the analysis and the findings are accomplished descriptively.

\section{Discussion}

\subsection{Characteristics of Toxic Relationship}

Based on the theory proposed by Effendy (2019), the characteristics of Toxic Relationship reflected in the story covers excessive romantic jealousy, egoism (selfishness) of the partner, and lack of honesty.

\subsubsection{Excessive Romantic Jealousy}

Excessive jealousy is one of the characteristics of toxic relationship. It can be caused by various things, such as intimate behavior of a partner with a third person, sexually or emotionally involved with someone else; intimate contact of the partner with a third person upon slight indications of interest. Excessive jealousy in this study is caused by the intimate behavior of a partner with a third person. It can be seen in the following quotation:

Hardin and Molly are sitting right in my eye range, I can see Hardin's entire face through the space between Steph and Tristan's shoulders. If I just look once, I couldn't hurt. I look at Hardin before I can stop myself and instantly regret it. His arm is hooked around Molly's shoulders. Why did I have to look? The pang of jealousy I feel is my punishment for looking at him when I shouldn't be. Of course they are probably messing around again, or still. They probably never stopped. I remember how comfortable she was straddling him at the party and I swallow the bile rising in my throat. Hardin is free to do whatever or whoever he pleases. (Todd, 2021: 42)

The quotation describes that Tessa is jealous of seeing Hardin with another girl named Molly. She was Hardin's closest friend before he met Tessa. Her jealousy is uncontrollable because she knows that Hardin once made out with Molly. It really hurts 
her to remember that her boyfriend slept with another girl even before they met each other. In addition, when Tessa meets Hardin in the cafe, Hardin's position with Molly is so intimate. It makes Tessa feel uncomfortable. Moreover, Tessa's jealousy can be seen clearly in the following quotation:

"Thanks for the ride" I say sarcastically. "You might want to hurry and get back to Molly" I add as I climb out. I hope he didn't hear me, I am not sure why I even said that. "Yea I better, she sure is fun when she is drunk" he smirks. I try to hide the fact that I feel like he just punched me in the stomach. I lean down to look at him through the passenger window and Hardin rolls it down. (Todd, 2021: 44)

The quotation shows that Tessa's Jealousy is uncontrollable. She acts like she does not care about Hardin and Molly, but it also makes her uncomfortable to hear Hardin's answer when she asks Hardin to go back to the café so he can make fun of Molly without her. It is shown when she feels like Hardin has just punched her in the stomach.

\subsubsection{Egoism (Selfishness) of the Partner}

In toxic relationship, egoism becomes one of the prominent problems between partners. The selfishness that usually occur such as prioritizing their own interest over the interests of others, difficulty accepting suggestions if it has no beneficial to themselves, not cooperative, willing to win alone, little tolerance, lack of empathy, calculation, lack of understanding, stubbornness. The egoism in this study can be seen from the quotation below:

"I don't know. We haven't known each other that long. I had always thought I wouldn't live with anyone else until I was married." I explain. That's not only the reason, my mother is a huge reason along with the fear of having to rely on someone else. Even Hardin. "Married? That's an ancient idea you have there Tessa." He chuckles and sits down in the chair. "What's wrong with marriage?" I ask. "Not between us. Just in general." I add. "Nothing wrong with it, it's just not for me." He shrugs. This discussion has taken too serious of a turn. I don't want to speak about marriage with Hardin, but it does bother me that he says marriage isn't for him. (Todd, 2021: 83)

Egoism from the quotation above can be seen from what Hardin says that marriage is not for him. He just wants to live together with Tessa but does not want to marry her. In his opinion marriage is only an ancient idea. They can live together without marriage. But for Tessa, she just wants to live with anyone else until she is married. Hardin always says what he wants to do without thinking about Tessa's feeling. It is such an egoism that Hardin does to Tessa. Another egoism that Hardin does to Tessa can be seen in the following quotation:

Are you embarrassed of me or something? I mean I get it, I am not exactly the cool girl but I thought.." "What? No! Of course I'm not embarrassed of you. Are you crazy?" He huffs. I feel crazy at the moment. "Why did you introduce me as your friend? You keep talking about living together and then you tell them we are friends? What are you going to do, hide me? Not tell anyone? I won't be anyone's secret. If I am not enough for your friends to know we are together 
then I don't want to be." I turn on my heel and walk away after my speech. (Todd, 2021: 85)

This quotation shows that Hardin is very selfish. Besides he does not want to marry Tessa, he also do not want to tell his friends that they are together. He just introduces Tessa to his friends as a friend. It exactly hurts Tessa's feeling and makes her think that she is not enough for him. Hardin keeps talking about living together but he is not only does not want to marry Tessa but also does not want to let his friends know that they are dating. He always wants to win alone without thinking about Tessa.

\subsubsection{Lack of Honesty}

Honesty in a relationship is a very real value that we should do everything in our power to keep alive. The health and longevity of the relationship depends upon it. In this study, the lack of honesty that Hardin has done is that Hardin is dating Tessa just for a bet in the first. But by the time it goes by, he really loves Tessa and wants Tessa to be his for real. However, he does not tell the truth to Tessa and just keeps it a secret. He cannot be honest to Tessa and finally Tessa knows it from Molly and it really hurts Tessa's feelings because she thinks that what they have done together all this time is not more than a bet. The lack of honesty that Hardin does can be seen in the following quotation:

"You're really taking this whole thing a little far aren't you?" Molly raises an eyebrow. "Molly I swear to god if you don't shut the fuck up.." Hardin threatens her. "What thing? What he is taking too far?" I can't help but ask. "Tessa, go outside." He commands but I ignore him. "No, what is he taking too far? Tell me!" I yell. "Wait.. you're in on it aren't you?" She laughs and continues, "I knew it! I told Jace you knew but he wouldn't believe me. Hardin you owe Zed some big bucks for this." She throws her head back and stands up. Hardin's face is completely pale, all the blood seems to be drawn from his entire body. My head is swimming and I am so confused. I briefly glance and Nate, Tristan and Steph but they are all focused on Hardin. (Todd, 2021: 100)

The quotation shows that Tessa is very confused about what Molly is talking about. She really has no idea of what is actually happening. Hardin keeps trying to keep Molly from telling the truth. This makes Tessa even more curious about what they are hiding from her and makes her keep pushing Molly to tell the truth. Tessa already knows that what they are hiding is not a good thing. Because at that moment, Hardin's face turned pale like a frightened person. His lie is finally exposed after Molly and Jace keep pushing him to tell Tessa the truth.

\subsection{Negative Impacts of Toxic Relationship}

Negative impacts of toxic relationship is also explained in this study. It includes disrespect and abuse.

\subsubsection{Disrespect}

Respect is an important component of a healthy relationship. People should treat their partners well to respect them. But in toxic relationship, there is no respect or often 
called disrespect. Disrespect can take many forms, but typically has the same outcome. Disrespect often becomes the common reason for breakups. In this study, disrespect happens because of the rudeness of Hardin. He often talked rudely to Tessa. She realizes that, but she still tries to forgive Hardin until one day she feels tired of Hardin's very bad attitude towards her. This can be seen from the quotation below:

"I am difficult? You have to kidding me! What do you expect me to do Hardin? You are cruel to me, so cruel." I say and pull my bottom lip between my teeth. I will not cry in front of him. Noah has never made me cry, we have been in a few fights over the years but I have never been upset enough to cry. "I don't mean to be" his voice is quite. "Yes you do and you know it. You do it purposely. I have never been treated this poorly by anyone in my entire life" I bite my lip harder. I can feel the knot in my throat. If I cry he wins. That's what he wants. (Todd, 2021: 33)

From the quotation above, it describes how Tessa feels about Hardin's bad attitude towards her. She has never been treated as badly as what Hardin did to her. Hardin is very cruel. He likes to talk to Tessa rudely. He says that he does not mean to be like that, but he keeps doing it many times. It is so bad to be treated cruelly by someone that she loves the most. She does not even want to cry in front of Hardin anymore, so that Hardin never thinks that he wins because Tessa wants to cry over him after the cruel things he did.

Besides being rude to Tessa, Hardin's disrespectful treatment to Tessa has also been seen since the beginning of their relationship, where Hardin does not want to have a commitment with Tessa but only wants to be friends with benefit. It can be seen from the quotation below:

"We aren't that different, we are very similar. We like the same things, we both love books for example." He says. I can't wrap my mind around the idea of Hardin trying to convince me that we could be good together. "You don't date." I remind him again. "I know, but we could.. be friends?" There it is. We are back to square one. "I thought you said we couldn't be friends with you. I know what you mean by that. You want all the benefits of being my boyfriend without actually having to commit to me." His body sways and he leans on the table and loosens his grip of me. "Why is that so bad? Why do you need the label?" "Because Hardin, I have self-respect. I will not be your play thing, especially when it involves being treated like dirt. I am already taken Hardin.” (Todd, 2021: 34)

The quotation explains that at the beginning of their relationship, Hardin does not want to have a commitment with Tessa. He just wants to be Tessa's friend but also takes the benefits just like they are in a relationship. Tessa refuses it because she has self-respect. She does not want a man to take the benefits from her without love, or commitment. Because Hardin thinks that the label "boyfriend" is not that important, but for Tessa, commitment is a form of respecting a partner. 


\subsubsection{Abuse}

In this study, the kind of abuse that Hardin does to Tessa is emotional abuse. Emotional abuse is a way to control another person by using emotions to criticize, embarrass, shame, blame, or otherwise manipulate another person. Hardin often talks rudely to Tessa, insults, gives cruel critics that can make Tessa sad and feel low. It can be seen from the quotation below:

"I don't know why you got all dressed up just to go to my dad's when I am not even going. It's weird" he snaps out of nowhere. I roll my eyes and mentally bang my head against window. I knew this behavior wouldn't last. I ignore his insult and just wait for the next. (Todd, 2021: 49-50)

From the quotation above, it is shown how Hardin insults Tessa just because of Tessa wearing a good dress to attend a dinner at his father's house. He does not want to attend dinner, but then he humiliates Tessa to make her in a sour mood. Tessa feels bad for what Hardin says to her. It can be seen from the quotation below:

"Yes, it is. You have no reason to be upset with me and here you are insulting me and making fun of me. All I'm doing is trying to look decent to go to dinner with your family when you refuse to." I breath. (Todd, 2021: 50)

It is shown that Tessa realizes how Hardin insults her, but he still wants to be upset with Tessa because Tessa wants to go to dinner with his family. She dresses up well to look good and decent in his family. It is the kind of respect that she does for his family even when he cannot respect Tessa.

\section{Conclusion}

After doing the analysis about toxic relationship including the characteristics and negative impacts, there are several points that need to be concluded. The conclusions can be described through the points below:

1. There are three characteristics of toxic relationship that can be found in the After story. They are excessive romantic jealousy, egoism (selfishness) of the partner, and lack of honesty.

2. The negative impacts of toxic relationship that can be found in the story are disrespect, inequity, lack of care, and abuse.

3. In the After story, the person most affected by a toxic relationship is Tessa.

4. Excessive romantic jealousy occurs because Tessa knows that Hardin once makes out with Molly, and when Tessa meets Hardin in the cafe, Hardin's position with Molly is so intimate.

5. Hardin just wants to live together with Tessa but does not want to marry her and introduces Tessa to his friends as a friend. It is such an egoism that Hardin does to Tessa.

6. Lack of honesty is the root of the problem that causes toxic relationship. Tessa is very disappointed because Hardin does not tell the truth that he is dating her just for a bet.

\section{References}

Aaker, D. (2001). Marketing Research, Seventh Edition. USA: John Wiley \& Sons, Ind. 
Asendorpf, J., \& Banse, R. (1992). Psychology of Relationships. Berlin: Springer.

Borg, Walter R. and Gall, Meredith D. (1989). Educational Reseach: An Introduction. Michigan: Longman

Buunk, A. (1997). Personality Birth Order and Attachment Styles as Related to Various Types of Jealousy. Personality and Individual Differences, 997-1006.

Byrd, Rebekah J. et.al (2009). Human Services Trainees' Conceptualization of Dating Relationships: Implications For Counseling Adolescents and Young Adults. Human Service Today, 6 (1), 1-9.

Clanton, G. (1996). A Sociology of Jealousy. International Journal of Sociology and Social Police, 171-189.

Corsini, Raymond J. (2018). Current Psychotherapies. San Francisco: Cengage Learning.

Djaba, Georgette. (2009). Raising Honest Children. Feature Article. Accessed from http://www.modernghana.com/news/246124/1/raising-honestchildren.html, (June 2021).

Effendy, Nurlaila. (2019). "Pendekatan Psikologi Positif Pada Toxic Relationship", (Dipresentasikan Dalam Seminar Mahasiswa Psikologi UNY, 20 Desember 2019) http://www.uny.ac.id/berita/pendekatan-psikologi-positif-pada-toxicrelationship (June 2021).

Glass, Lillian. (1995) Toxic People. California: Simon \& Schuster.

Gordon, Sherry. (September 2020). https://www.verywellmind.com/identify-and-copewith-emotional-abuse-4156673 (June 2020)

Hardie, J., \& Lucas, A. (2010). Economic Factors and Relationship Quality Among Young Couples: Comparing Cohabitation and Marriage. Journal of Marriage and Family.

Hart, S., \& Legerstee, M. (2013). Handbook of Jealousy; Theory, Research, and Multidisciplinary Approaches. Londres: Wiley-Blackell.

Kelly, H. (1983). Analyzing Close Relationships: Development and Change. New York: Freeman.

Khanam, Amera. 2013. Relationships, Honesty and Islam. Article. http://youlki.blogspot.com/2013/07/relationships-honesty-andislam.html, (June 2021).

Merriam, George and Merriem, Charles. (2001). Merriem-Webster Dictionary. Massachusetts: Merriem-Webster Com.

Neyer, F., \& Lehnart, J. (2006). Personality, Relationships, and Health: A DynamicTransactional Perspective. UK: John Wiley \& Sons.

Pfeiffer, S., \& Wong, P. (1989). Multidimensional Jealousy. Journal of Social and Personal Relationship, 181-196.

Reis, H. (2001). Relationship Experiences and Emotional Well-Being. New York: Oxford University Press.

Sullivan, H. (1953). The Interpersonal Theory of Psychiatry. New York: Norton.

White, G. (1981). Jealousy and Partner's Perceived Motives for Attraction to a Rival. Social Psychology Quarterly, 44, 24-30.

Wulandari, Primatia Yogi. (2019). "Waspada Toxic Relationship Semakin MeningkatSetiapTahunnya".Unairnews.http://news.unair.ac.id/2019/12/26/wasp ada-toxic-relationship-semakinmeningkat-setiap-tahunnya/)

Zeid, Mestika. 2004. Metode Penelitian Kepustakaan. Jakarta: Yayasan Obor Indonesia. 